\title{
THE POLITICS OF CONSTITUTIONAL CHANGE
}

\author{
J. R. MALLORY*
}

One of the most useful characteristics of federalism is that it makes it possible to offload some issues which produce conflict in the system onto regional units, where local majorities can achieve policies never acceptable to the country as a whole. The persistence of such conflict if they cannot be hived off in this way can overload the system, poison its politics, and reduce it to the immobility of a political stalemate. It is well known that the political leaders in the province of Canada attempted to overcome such avoidable conflict through the device of federation with the other provinces of British North America. The most troublesome conflict was the schools question. In Lower Canada (which became Quebec) the substantial Catholic majority was content with nothing less than a Catholic school system, an anathema to the Protestant majority in Upper Canada (which became the province of Ontario). The best way to resolve this divisive struggle was to make education a provincial responsibility, while at the same time inserting a guarantee in the constitution protecting the right to separate schools to "the Queen's Protestant and Roman Catholic subjects" in both provinces. Similarly, the historic right to preserve the civil law, rather than the common law, in Quebec made it essential that civil law and procedure should be a provincial concern.

All federal constitutions have a certain rigidity, necessary to protect the perceived interests of their component parts. Through time the environment changes, demands on government alter, and later generations may find the old form irksome and possibly irrelevant. How can they be changed without generating conflicts which put excessive strain on the system? This is a perennial problem with federations, amplified in the last hundred years by the rapid changes brought about by modernization. In Canada the pressure for change has reverberated through the political system, colouring the motives of politicians and governments, and inevitably involving the courts in the task of discerning and redefining the original bargain in contemporary terms.

The framers of the Canadian Constitution thought that they had designed a flexible constitution with a strong and adaptable role for the central government. To them the lesson of the American Civil War was that the existence of strong and immutable states' rights threatened the survival of the whole enterprise. This was a mistake that the framers had no intention of repeating. They envisaged a strong and dominant role for the central government, endowed with ample powers to carry out the great task of expansion and development. Many of the framers

Copyright $(\mathcal{C} 1983$ by Law and Contemporary Problems.

- Emeritus Professor of Political Science, McGill University. 
would have preferred a unitary form of government, but "they could not ignore the social forces rooted in the history of the colonies any more than they could presume to bind the future indefinitely to the past."' The result of the framers' effort was a strongly centralized union in which provincial powers and functions were strictly limited and confined, it was thought, to issues of local importance which would have produced irreconcilable divisions at the national level.

It was thought that rigidly confining jurisdiction in separate spheres would reduce conflict to manageable issues, reconcilable within one or the other of the jurisdictions. In the ideal form of classical federalism each level of government can go on serenely cultivating its own jurisdiction almost as if the other did not exist. The real world, however, does not seem able to adjust itself to this model. Conflict emerges between the two levels of government, and some way has to be found to settle such conflict. At bottom, this political conflict is the result of the actions of political men intent on defending political space, which to them in a federal system is largely defined in jurisdictional terms. If jurisdictions do not seem adequate to this territorial imperative, there will be pressure to redefine the boundaries of the constitution. Where formal amendment is too difficult to achieve, political bargaining and/or litigation over jurisdiction may achieve nearly the same result.

The initial method of conflict management, which frequently involved constitutional issues, sheds a strong light on the nature of the system the founders had put together in the British North America Act. It was based more on a colonial than a federal model. This is not surprising. The Canadian statesmen who founded the union had grown up in a colony in which they enjoyed limited powers of self-government under controls operated by the British government. These controls were both executive and legislative. Colonial governors were armed with elaborate instructions as to which measures they were free to approve and which should be referred to the Colonial Office for final action. This was called the power of reservation, by which the governor, instead of giving assent to a bill, could reserve it "for Her Majesty's pleasure" so that the final decision to approve the bill was taken by the British Colonial Secretary. If a governor was sufficiently lacking in vigilance that he failed to reserve such a bill, the act itself could be nullified within two years by the British government exercising the power of disallowance. These powers over the new government of Canada were retained in London, but in fact they rapidly fell into desuetude.

In the provinces, similar powers of reservation and disallowance were vested in the lieutenant-governor of the province and the governor general of Canada respectively, but from the beginning the powers were exercised on the constitutional authority of Canadian ministers. Accordingly, Ottawa had the same "imperial" powers over the provinces that the British government had over the Dominion of Canada. But while the British powers of control atrophied, the powers of the central government were strongly asserted. Sir John A. Macdonald,

1. I Royal Commission on Dominion-Provincial Relations [RoWell-SiRois] Report Book I, $36(1940)$. 
who led the federal government as Prime Minister for many years before his death in 1891 , initially also held the portfolio of Minister of Justice. In that capacity he announced in 1869 "that the Federal Government would be called upon to consider the propriety of allowance or disallowance of provincial enactments much more frequently than the Imperial Government had done in the recent past."2 Over the next thirty years fifty-one bills were reserved and sixty-five acts were disallowed. ${ }^{3}$ The federal government

claimed the substantially judicial function of deciding whether provincial legislation was ultra vires. It stood ready to invalidate provincial enactments which it thought unjust or contrary to sound principles of legislation. It was prepared to veto legislation which, according to its view, conflicted with imperial treaties or policies, or with Dominion interests and policy. ${ }^{4}$

Such a one-sided method of dispute settlement was not likely to sit well with provincial governments, and it did not. In 1887, the premier of Quebec summoned a conference of his fellow premiers, and also invited Prime Minister Macdonald. The latter refused to attend, on the ground that the legitimate representatives of the provinces were the members of parliament at Ottawa. The political overtones of the meeting were obvious; two of the five provincial premiers did not attend, and the premiers who did were not of Macdonald's party. The conference resolved that the disallowance power should be taken away from the federal government and that resort to the courts was a better method of settling such disputes. 5

By this time Confederation was twenty years old. One of the effects of the great world depression, which began in the 1870's and lasted for over twenty years, was the weakening of the authority of the federal government. Provincial resistance to national policies was fueled by regional discontent. The role of the provinces as agencies of government was greatly strengthened by two other factors. One was the growing importance of extractive industries, such as forestry and mining, heavily dependent on provincial governments both for the infrastructure of roads and of electric power, and for the allocative role of granting leases on provincially controlled natural resources. The second factor, a consequence of growing urbanization and industrialization, was the new demands on government for alleviative measures which could be achieved under provincial jurisdiction. Such measures at the time of Confederation were inhibited by the dominant doctrine of laissez-faire, but thereafter a growing role for the state in the social sphere became increasingly respectable. ${ }^{6}$ New roles for government in federal systems raise questions of which level of government is to carry them out. These questions may be settled authoritatively by the courts, which thus legitimize constitutional adjustments and, in this manner, act as part of the machinery of constitutional amendment.

2. Id. at 49 .

3. Id.

4. Id. See also G. Laforest, Disallowance and Reservation of Provincial Legislation (1955); J. Mchenry, Memorandum on the Office of Lieutenant-Governor of a Province (1955).

5. LAFOREST, supra note 4 , at $58-59$.

6. See J. Mallory, Soclal Credit and the Federal Power in Canada (1954). 
The courtroom battles of this era can be seen as political in the sense that the vested interests which initiated them-having lost the battle at the ballot-box and in lobbying ministers against regulations they did not like-were continuing the political contest by other means. This was certainly true of some of the earlier cases. In the landmark case of Russell $v$. the Queen, ${ }^{7}$ the federal government did not appear in the case even though it involved a jurisdictional question that disputed the general power of parliament to legislate even in areas which appeared to fall under provincial jurisdiction over property and civil rights.

In later cases the politicians were not so innocent, and the courts became an important arena of federal-provincial conflict. One of the most important of these cases was the "Local Prohibition Case."8 In Russell the court had upheld a federal statute permitting local areas to impose prohibition of the sale of alcoholic beverages. In the Local Prohibition Case the question was whether, notwithstanding Russell, a province possessed the power to regulate the liquor traffic in a variety of ways. This case was a direct confrontation between the province of Ontario (with Quebec and Manitoba as intervenors) and the Government of Canada. The court upheld the provincial power, and in so doing strictly limited the general legislative power of parliament. The decision meant that, except in unspecified extraordinary situations, parliament's general legislative power could not be exercised in any of the enumerated fields of provincial jurisdiction. The effect of the decision in the Local Prohibition Case and others was to shift the balance of Canadian federalism toward the provinces.

As the depression receded, much of the energy of the federal government was absorbed by the completion of the transcontinental railways, the management of land settlement on the prairies, and the development of the wheat economy. In the meantime, provincial governments steadily expanded their own responsibilities in their own spheres. The result was a federal system much closer to the classical model, in which each level of government functioned autonomously in its own sphere of activity. Inevitably there were conflicts of jurisdiction, which were resolved by the courts. By the beginning of the first World War, thirty years of constitutional interpretation had created a situation in which each level of government was reasonably capable of meeting the demands laid upon it by the political system.

The depression of the 1930's put a severe strain on the constitutional arrangements which had developed as a result of the judicial interpretation of the past. The enhanced provincial jurisdiction over welfare and social policy, which the courts not unreasonably confirmed in the simpler days of the nineteenth century, proved to be an unhappy legacy when the provinces and municipalities staggered under the burden of providing relief for the unemployed and the destitute. The distribution of financial resources in the constitution had now become totally inadequate to meet provincial requirements. Provincial revenue sources were limited and inelastic, insufficient for even the richest provinces. On the other hand, the

7. (1882) 7 App. Cas. 829.

8. Attorney-General of Ontario v. Attorney-General of Canada, [1896] A.C. 348. 
federal government, which possessed the major sources of revenue, lacked the jurisdiction necessary to deal directly with the social and economic problems created by the depression.

At first the government in Ottawa extended financial aid to the hard-pressed provinces, albeit on a scale inadequate to meet the problem. Inevitably it was driven to enlarge its jurisdiction to fill the gap. In part inspired by the example of the New Deal in the United States, Prime Minister Bennett's Conservative government belatedly introduced its own measures, including the regulation of hours of labour and the introduction of a plan for unemployment and social insurance. These measures were held by the Judicial Committee of the Privy Council to be beyond the federal government's legislative powers. ${ }^{9}$ The rulings created a virtual no-man's land in the constitution. The federal government had the resources to deal with problems now national in scope, while the provinces had the jurisdiction but neither the financial means nor the bureaucratic capacity to deal with the problems effectively.

Some provinces, notably Alberta, intervened directly to deal with the pressing problems of farm debt through the creation of debt-adjustment legislation, and to deal with the more general problem by seeking to institute a regime based on Social Credit doctrines. The federal government considered this legislation an infringement upon its territory. Its sacred jurisdiction over interest rates, banking, and monetary policy was strongly defended in the courts, initially by the mortgage and lending interests, and the federal power was further defended by the revival of disallowance. ${ }^{10}$ Federal-provincial conflict thus emerged as a dominant theme of the 1930's.

The liberal government of Mackenzie King responded with typical caution. At the same time it was defending its essential jurisdiction against provincial inroads, it appointed a royal commission of enquiry to investigate the whole field of federal-provincial relations. The Commission took three years to complete its hearings and to ponder a substantial volume of research. Basically its report reaffirmed its faith in the federal system, but some important modifications of jurisdiction were recommended. These included the transfer to the federal government of jurisdiction over unemployment insurance, which was considered administratively inappropriate for provincial jurisdiction. The most important recommendation was for a major revision of federal-provincial financial relations, with the creation of an impartial grants commission to administer the transfer of funds to "havenot" provinces so that they could provide reasonable levels of service within their jurisdictions at reasonable levels of taxation. The Commission rejected, largely on the grounds of inefficiency and lack of accountability, jointly-financed programs. The result of implementing the Commission's recommendations would probably

9. Attorney-General of Canada v. Attorney-General of Ontario, [1937] A.C. 326 (P.C.); AttorneyGeneral of Canada v. Attorney-General of Ontario, [1937] A.C. 355 (P.C.); Attorney-General of British Columbia v. Attorney-General of Canada, [1937] A.C. 377 (P.C.).

10. See MALLORY, supra note 6. 
have been to reduce federal-provincial conflict by making the provinces more financially secure in their own jurisdictions.

The apparent inadequacies of government in the 1930's led to increased awareness that some constitutional amendment reallocating power between the two levels of government seemed unavoidable. The question of the procedure of formal amendment, which had long remained dormant, suddenly became an issue. For reasons which are not entirely clear, the Canadian Constitution did not include a complete amending procedure in 1867. In most major areas, amendment to the British North America Act legally remained with the British Parliament. This arrangement became increasingly incongruous with the growth of dominion status and the formal legal equality between the self-governing dominions and the United Kingdom proclaimed by the Statute of Westminster.

As a result of provincial protests it became necessary to insert a section in the Statute of Westminster exempting the British North America Acts from its effect. It was assumed that an appropriate amending formula would be found. It was not. While apparently all that was necessary for the British Parliament to amend the British North America Act was a joint resolution of both Houses of the Canadian Parliament, prudence dictated that provincial consent was necessary where a reallocation of powers was concerned. ${ }^{11}$ Provincial premiers learned to barter their consent at a high price, so that numerous attempts to find an acceptable amendment formula, and to "patriate" the constitution, failed.

The attempt of the Royal Commission on Dominion-Provincial Relations to rewrite a truly federal constitution in the light of twentieth-century demands on government also failed. The Dominion-Provincial Conference, called to discuss the report on January 14 and 15, 1941, broke up without agreement. However, a totally different approach to the problem emerged as a result of the wartime arrangements for economic management. The impact of total war had the incidental effect of reducing provincial governments to spectators since many of their normal fields of jurisdiction were assumed by the federal government under the War Measures Act. Scarcity of materials ensured that some of their most visible activities, such as public works, ceased. Wartime full employment solved the problem of relief for the unemployed. Under wartime taxation agreements achieved in 1942, the provinces temporarily surrendered the income, corporation, and succession duty taxation fields to the federal authorities in exchange for guaranteed revenues.

Other factors contributed to a major change in the Canadian federal system. The skillful application of the doctrines of Keynesian economics by the Department of Finance seemed to demonstrate that the management of the economy could be achieved largely by fiscal and monetary means. Consequently, the need for jurisdictional reallocation in favour of the central government receded. Constitutional revision, with all its divisive implications, could wait. Nevertheless, it was clear that public expectations of an expanded role for government in the fields of

11. P. Gérin-Lajoie, Constrtutional amendment in Canada (1950); G. Favreau, The AmendMENT OF THE CONSTITUTION OF CANADA (1965). 
social security, health care, and the like, had risen sharply. The British Beveridge Report, with its promise of social security "from the cradle to the grave," was echoed in Canada by similar proposals for post-war reconstruction.

The problem facing the federal government at the end of World War II was to find a way of managing such policies within the framework of the federal constitution. The innovative capacity of federal politicians and civil servants, sustained by the high prestige of the federal government from its management of the war economy, suggested a way to achieve the result without noticeable constitutional change. The provinces had the jurisdiction, but not the administrative and fiscal capacity, to undertake post-war measures of full employment and social security. All that was necessary was for the federal authorities to define the policy objectives, set the administrative norms, and offer financial incentives to get the provinces to join in unified measures to tackle the problems. Though this approach would probably lead to prolonged negotiation between the levels of government, the chances of serious conflict were initially slight. Federal proposals had the initial momentum of strong public support, which made them difficult to resist, while the provincial governments, with anemic bureaucratic support, had little capacity to resist. ${ }^{12}$

There is a danger that complex intergovernmental arrangements will run afoul of the constitution. The strict "water-tight compartment" view taken by the courts in the 1930's could easily have frustrated attempts to achieve common policy objectives. As Lord Atkin observed,

Unless and until a change is made in the respective legislative functions of Dominion and

Province it may well be that satisfactory results for both can only be obtained by co-operation. But the legislation will have to be carefully framed, and will not be achieved by either party leaving its own sphere and encroaching upon that of the other. ${ }^{13}$

It must be remembered, however, that the courts are essentially passive instruments of conflict resolution. If nobody wants to go to court, the constitution ceases to be an active ingredient in the situation. This was largely true in the years immediately following the war. The great corporations, many of whose officers had been wartime civil servants, had learned the benefits of government control of the marketplace and had little disposition to fight last-ditch battles in the courts. Similarly, provincial governments at that time were generally hesitant to start a challenge in the courts which might have large and unforeseen effects on the whole edifice of post-war economic and social policy. Furthermore, perhaps in part because the Supreme Court Act amendment of 1949 made the Supreme Court the court of last resort in Canada, the courts proved to be more accommodating than before to the imperatives of government, even when the bending of constitutional rules was involved. Thus, in P.E.I. Potato Marketing Board v. H. B. Willis, Inc., ${ }^{14}$ the Supreme Court upheld the provisions of the Agricultural Products Marketing Act

12. See D. Smiley, The Canadian Political Nationality (1967), for an excellent discussion of the developments, and R. Simeon, Federal-Provincial Diplomacy: The Making of Recent Policy in CANADA (1972), for an analysis of the process.

13. Attorney-General of British Columbia v. Attorney-General of Canada, [1937] A.C. 377.

14. [1952] 2 S.C.R. 392. 
of 1949 which empowered the federal government to delegate to a provincial board the power to make and enforce regulations. This decision neatly got around the constitutional difficulty which confined federal jurisdiction to international and interprovincial trade, but excluded it from wholly intraprovincial trade.

The federal-provincial conference, whether of first ministers, of ministers in a particular field, or even of officials, thus emerged as the dominant method of conflict resolution in this period. It was the era of "cooperative federalism" in which the two levels of government combined federal funding and initiatives with provincial administration in an incestuous relationship which seemed to make constitutional disputes largely irrelevant. Of course, there were conflicts, mostly about details and funding, but they were manageable when the policy objectives of the two levels of government were complementary. Only the Province of Quebec, which until 1960 preserved an implacable hostility to federal-provincial cooperation of this sort, stayed out of joint programs altogether, evidently willing to pay a high price in funding in the interests of constitutional purity.

The increasingly intimate relationships between the two levels of government in cooperative programs led to conflicts over both ends and means. Many of these conflicts were a consequence of the entry of Quebec into active participation in federal-provincial programs. It was a time of furious activity in Quebec-a "Quiet Revolution" in which politicians and bureaucrats steadily expanded the reach of government activity in order to modernize Quebec society. To the Quebec negotiators the new cooperative program modes that satisfied most of the other provincial governments did not take account of the special needs of the different social and cultural milieu of Quebec. This led them to seek a "special status" for Quebec, which would retain full powers over programs subject to uniform treatment in the rest of Canada. Throughout the 1960's and 1970's a significant political issue was the pressure to incorporate a "two-nation" concept into Canadian federalism.

By this time nearly all provincial governments had developed a sophisticated planning and bureaucratic capability, shifting the level of expertise at federal-provincial conferences away from the federal side. Among other things, better provincial capability meant that real conflicts emerged when conflicting priorities surfaced in the negotiation of jointly financed programs. The emollient style of Prime Minister Pearson, while achieving solutions to differences as they arose, threatened to erode federal powers in key areas. This became an urgent problem in the late 1960's when the declining economy put a limit to federal largesse. No longer would it be possible to fund new programs out of federal revenues which grew automatically with a rising gross national product. If, increasingly, the federal government's role was merely to administer fiscal transfers to fund provincial programs, the federal government would be perceived as a tax-gatherer which conferred no visible benefits on the electorate-a prospect which alarmed federal politicians.

Nevertheless, intergovernmental negotiation and cooperation continued to be the mode of political life which provincial governments preferred. To them it was 
a much better means of conflict settlement than resort to the courts, the outcome of which had all of the disadvantages of a zero sum game. Thus, when the federal government referred a jurisdictional dispute over offshore oil to the courts, "it was widely interpreted as a violation of the rules of the game since the matter was a political conflict which should be settled politically."15 A decade later the government of Saskatchewan felt equally injured when, in two disputes over mechanisms of provincial management of oil and potash, which some of the affected companies had contested in court, the federal government appeared at the side of the companies as intervenor to protect its own jurisdiction. ${ }^{16}$

The decline of the role of the courts in constitutional adjustment was only partially the result of the political bargaining method of settling federal-provincial conflicts. It also stemmed from a provincial distrust, largely but not wholly in Quebec, of the impartiality and authority of the Supreme Court of Canada. The Court was a creation of the federal parliament, which could modify its jurisdiction, alter its composition, or even abolish it at will. The judges are appointed by the federal government, which means that critics unfamiliar with the obtuseness, independence, and unpredictability of judges will suggest that the Court will have a centralist bias in constitutional cases. As Premier Lévesque is fond of saying, the Court is like the leaning tower of Pisa, which always leans the same way. Provincial governments have thus become reluctant to use the court to settle disputes. Only the present Quebec government has the opportunity to have it both ways. If they prefer negotiation to litigation they usually gain more, while if they resort to litigation and lose, it only proves their point that the present federal system is unworkable.

Of all the federal-provincial negotiations of the last twenty years, perhaps the most intractable has been the impasse over the amending procedure in the constitution. Perhaps because it was perceived as a divisive issue at Confederation, the procedure had been left undefined. The provinces had the right to amend their own constitutions except in regard to the office of lieutenant-governor, but a number of important matters, such as the division of legislative powers between the two levels of government, were left to the British Parliament. Even before the Statute of Westminster of 1931, it was generally assumed that the role of the British government and Parliament in this matter was purely formal, and the necessity of occasionally amending the British North America Act was an anomaly which would be removed as soon as agreement on an appropriate form of amending procedure could be reached in Canada. Such an agreement had been tantalizingly unattainable for over fifty years.

The matter has taken so long, partly because constitutional adaptation by either judicial interpretation or intergovernmental agreement has sufficed. Since

15. R. Simeon, supra note 12, at 30. See also In re Offshore Mineral Rights, [1967] S.C.R. 792 (Can.).

16. Canadian Indus. Gas and Oil Ltd. v. Saskatchewan, 65 D.L.R. 3d 79 (Sask. Ct. App. 1975); Amax Potash Ltd. v. Saskatchewan, [1976] 6 W.W.R. 61 (Can.). At the moment a dispute over which government has authority to certify unions working on oilrigs has escalated the conflict between Newfoundland and the federal government over offshore oil. 
the achievement of an amending formula-like any other constitutional amendment-has always proceeded on the assumption that agreement of all of the provinces was necessary, attempts to achieve a more flexible formula were difficult. In large measure this was because no provincial government could readily agree to a formula by which any of its powers could be altered without its consent. In the case of Quebec there was the further fear that the achievement of "special status," which could imply an increase of its particular powers, would be vetoed by some of the other provinces.

The campaign to persuade Quebec voters to vote against the 1980 provincial referendum on sovereignty-association gave much added impetus to the desire for "constitutional renewal," especially among those federal ministers (including the Prime Minister) who came from Quebec. Negotiations were intense at the ministerial and official level as a prologue to the First Ministers" "summit" in September of 1980. Progress was made, but the summit failed. At that stage the objectives of the two sides were too far apart. The federal government wanted a reasonably flexible amending formula, which the provinces were willing to accept, but only at a price. Prime Minister Trudeau wanted above all to enshrine a Charter of Rights in the constitution in order to protect not only the usual political and legal rights, but also linguistic and educational rights for both French- and English-speaking Canadians. The eight dissenting provinces adopted the position that they would accept a flexible amending procedure, provided that each province had the right to "opt out" of any amendment which it did not like. This would not only meet the objectives of Quebec, but it would also satisfy those provinces which objected on principle to the idea of a bill of rights, or which were reluctant to concede language rights as a matter of law. This position was unacceptable to the Prime Minister, who felt that it would produce a checkerboard of different constitutional provisions applying differently in every jurisdiction.

Negotiation having failed, the federal government decided to go it alone, and it proceeded unilaterally to propose to the Canadian Parliament a package which included an amending formula, "patriation," and the Charter of Rights. This action was supported by only two provinces (Ontario and New Brunswick) and was bitterly opposed, for a variety of reasons, by the others. The federal government had armed itself with an outside legal opinion that in strict law there was no barrier to such action, and, when challenged in the House and elsewhere, ministers insisted that their proposal was not a constitutional issue but rather essentially a political one. They asserted that in the past the federal government, in seeking amendments, had always maintained the position that there was not a convention of the constitution which bound them to consult the provinces.

Even if there was a convention, what legal remedy existed for a breach of it? All legal authorities agreed that the convention was a nonlegal norm, the'breach of which could not give rise to a remedy in the courts. In general, the courts in both Britain and Canada had taken the position that they were not concerned with conventions but only with interpreting the law. Presumably they would do so again. Nevertheless three provinces proceeded, by way of reference to their courts of appeal, to challenge the federal action on both legal and conventional grounds. 
Two provincial courts (Manitoba and Quebec) upheld the federal position, while one (Newfoundland) found against it.

The matter went to the Supreme Court of Canada, which heard arguments in April 1981. On September 28 the Court delivered judgment. ${ }^{17}$ A minority of the Court, led by the Chief Justice, argued in essence that conventions were not a justiciable matter, and, in any event, the precedents were so uncertain that it was not possible to discover whether there was in fact a clear-cut convention. However the majority, while concluding that the federal initiative was legal, nevertheless maintained that there was a convention requiring provincial consent, so that the federal action was unconstitutional in the sense that it did not comply with the convention. The questions posed in the various references had only asked whether provincial consent was needed. No one had asked whether less than unanimous consent would suffice. And yet this is the question which the majority answered. It was not for them to specify what the convention was, they said, but clearly the support of only two provinces was not enough. There should be substantial provincial agreement. But what was substantial agreement? They did not say.

However bizarre the majority decision was as a piece of jurisprudence, it had a catalytic effect. A further First Ministers' Conference in November, after again coming very close to impasse, did in fact produce an agreement between the federal government and nine of the provinces. Quebec remained an outraged dissident. The new formula in effect took the "provincial" amending formula (twothirds of the provinces having more than fifty percent of the population), and included provisions by which provinces could override the guarantees of the Charter. In effect Quebec had bargained away its presumed veto on constitutional change in April by joining the dissident provinces in proposing the flexible amending formula with the accompanying right to opt out of amendments they did not like. Now its former allies had closed a deal with the federal government involving a less palatable and sweeping opting out formula. The prospect that Quebec will thus be reduced to the position of just another province may have profound political consequences for the future of Quebec-Canada relations. What the effects will be cannot now be readily foreseen, but this particular outcome could not have been expected unless the majority decision of the Supreme Court had taken the form that it did.

What does this episode tell us about the courts as arbiters of federal-provincial conflict? Up to a point the courts are necessary referees who can determine authoritatively what the constitution means. However, the law is an instrument for achieving precise answers to conflict. Two contradictory rights cannot coexist, and someone must determine which one prevails. Moreover, while federal-provincial conflict involves vague and complex issues, it is essentially a political conflict. The evidence of history suggests that democratic constitutionalism cannot tolerate an unbalanced diet of win-all/lose-all situations. Most of the time the system is better off with political compromises which are tolerable to all significant interests.

17. Reference Re Amendment of the Constitution of Canada, 125 D.L.R.3d 1 (1981). 
Consequently, strain on the system is minimized when there are effective political instruments to handle most kinds of conflict. But what if these institutions exacerbate conflict rather than contain it? One must then look at the system of government itself, the party system which underpins it, and the intergovernmental machinery which deals with federal conflicts.

Written constitutions-particularly federal ones-are notoriously hard to amend. Nevertheless, though their words may be difficult to change, their meanings change in response to changing conditions. As Dicey pointed out, these changes in accepted meanings- which are tantamount to constitutional amendments-become part of the constitution when they are sanctified by the courts. ${ }^{18}$ Political adaptations from intergovernmental bargaining can only go as far as the courts allow. The extent to which the courts are asked to adjust novel political arrangements into the framework of the constitution also depends on the extent to which these arrangements are challenged in litigation.

Resort to the courts can thus be seen as part of the political game of constitutional amendment. During the 1970's the Supreme Court of Canada was confronted with less than three cases a year having significant constitutional importance. ${ }^{19}$ The action was elsewhere, involving federal-provincial bargaining over a wide range of issues, such as joint programs, the renewal of five-year agreements covering fiscal transfers to the provinces, and shared fields of taxation. There were also discussions on the perennial question of constitutional amendment, including the achievement of a formula as well as the transfer of jurisdiction from one level of government to the other. To most provincial governments all of these issues were linked together, so that they would hold out hope of agreement on one if concessions could be made on some other issue. This explains the sense of outrage felt by the majority of provincial governments when the federal government seemed intent on proceeding unilaterally with its constitutional proposals whether they agreed or not. In that single gesture the federal government had nullified the provinces' strongest bargaining card-agreement on the constitution in exchange for jurisdictional or other concessions.

When normal bargaining fails to produce satisfactory solutions, there is a tendency for one or the other of the parties to escalate the conflict by resort to a more dangerous but possibly more effective weapon. Thus, collective bargaining can lead to strikes or lockouts, and diplomatic negotiations to war. In Canadian federal-provincial relations the next step is resort to the courts. Generally speaking, during the period of "cooperative federalism" neither the federal government nor the provinces deliberately sought to involve the courts, though from time to time jurisdictional conflicts were generated as a byproduct of some other conflict in society. ${ }^{20}$

18. A. Dicey, Introduction to the Study of LaW of The Constrtution 179 (10th ed. 1961).

19. Hogg, Jurisdiction of the Court: The Supreme Court of Canada, 3 CAN.-U.S. L.J. 44 (1980).

20. A recent example concerns the jurisdiction over offshore oil in relation to Newfoundland. The federal and provincial governments have been negotiating this issue for years, tacitly avoiding a final settlement in the courts in the hope of a political compromise. An application for union certification on the oilrigs raised the question of whether this fell under the jurisdiction of the Canadian or Newfoundland labour relations boards. The government of Newfoundland demanded that the federal government stop the liti- 
The abrupt change in their bargaining position which followed the federal threat of unilateral action on the constitution led the dissident provinces to open a second front in the courts by referring the constitutionality of the federal action to their own provincial courts of appeal. The whole process of constitutional amendment in Canada involves a number of informal steps which might or might not be based on conventions of the Canadian or British Constitutions. The only certain area governed by constitutional law is that covered by the Statute of Westminster. The courts have generally been reluctant to address conventions of the constitution. In their hearts the dissident provinces probably expected to lose, but the litigation would delay the process, just as parliamentary obstruction by their allies, the Conservative opposition in the House of Commons, had done when the federal government sought to push its resolution through parliament. By buying time they hoped to sway public opinion enough to shake the federal government's resolve, and, to an extent, they succeeded. The Supreme Court judgment was announced on September 28th. A further First Ministers' Conference reached a compromise on November 5th, clearing the way for the revised constitutional resolutions to go through both Houses of Parliament in time to be transmitted to the United Kingdom before Christmas.

However much the issue was settled in the rest of Canada, it had been settled without the participation of the province of Quebec, and this again raised a serious political issue with possible constitutional implications. The province of Quebec responded by yet another reference to its Court of Appeal, seeking to resolve the question whether sufficient provincial agreement necessarily involved the consent of Quebec. In part, this was intended as a delaying tactic, but it also raised one of the persistent ambiguities of the Canadian federation: are all provinces alike, or does Quebec-representing one of the "two nations"-have a special place which entitles it to veto issues deemed vital to French Canada? There have been political controversies in Canada in the past when Quebec has been in opposition to the rest of the country, from the controversy over the execution of Louis Riel in the wake of the Northwest Rebellion of 1885, through the issue of participation in imperial wars from the Boer War, to the conscription crises of both World Wars. Because one of the perennial preoccupations of Canadian statesmen has been to avoid or defuse such conflicts, there seems to have been a tacit recognition that the minimal unity necessary for Canadian survival depends on a series of special accommodations to recognize the existence of a "two nations" concept of federalism. Since the 1960's the conflict between Quebec and the federal government has been the most clear-cut of the issues which have strained the capacity of the Canadian political

\footnotetext{
gation and, when that was refused, referred the jurisdiction question to the Newfoundland Court of Appeal. On March 15, the Premier of Newfoundland called a general election on the issue, which he subsequently won by a large majority, as a means of putting further pressure on the federal government. Meanwhile, the Federal Court of Appeal managed to decide the labour relations case in favour of federal jurisdiction without addressing itself to the wider question of the oilfields. Shortly thereafter, on May 19, the federal government itself referred the question of jurisdiction over the Hibernia field to the Supreme Court without waiting for the decision of the Newfoundland Court of Appeal. This provoked cries of outrage in Newfoundland. This episode reveals how a conflict can escalate rapidly when the channels of negotiation do not work.
} 
system. The isolation of Quebec on the constitutional question may greatly enlarge this conflict.

The most visible actors in the process of constitutional readjustment are the governments, both federal and provincial. These governments, it should be noted, are more than the spokesmen of the sectional and national interests which they represent. They have interests of their own which are distinct from, and often more influential than, the people themselves. "[F]ederalism, at least in the Canadian case," as Alan Cairns has argued, "is a function not of societies but of the constitution, and more importantly of the governments that work the constitution."21 In other words, constitutional change is not merely a predictable response to wider societal changes, but a product of the interaction of the governments and bureaucracies that are strategically placed to shape the process of change. These governmental bodies command large resources of funds and programs, they constitute in their own right a substantial part of the population, and they are able to assert a territorial imperative without apparent support or interest from the public. The basic division of state functions in a federal system has also led political parties and interest groups to conform to this pattern as they play out their roles within the system. Cairns adds,

Contrary to all predictions, post World War II Canadian politics has not displayed an irreversible trend to centralization, nor the manifestations of capitalist contradiction in polarized class politics, creative or otherwise. Instead, the provinces, aided by secular trends which have enhanced the practical significance of their constitutionally-based authority, and by the deliberate improvement of their own bureaucratic power and capacity, have given a new salience to the politics of federalism and territorially based diversities it encompasses, reflects and fosters. ${ }^{22}$

This has imposed almost intolerable strain on the mechanisms of conflict resolution in the system. When the provincial governments-and for its own reasons the federal government - found that conflict resolution by the courts was an enterprise that was too risky to contemplate, they increasingly put their faith in the federal-provincial conference. Nevertheless this system itself has been less and less effective in recent years.

Unfortunately [says Cairns], the contemporary search for intergovernmental coordination confronts a set of conditions inimical to conflict resolution. Reconciliation of federal and provincial objectives is facilitated when one or the other level of government is passive, when one level of government is clearly dominant, when the scope of government activity is minimal, or when the two levels deal with discrete, separable sections of society and economy. ${ }^{23}$

This leads Cairns to the conclusion that there were few conflicts over jurisdiction in the early years after Confederation. Nevertheless there were far more conflicts than he suggests, but they were managed successfully, partly because nearly all of his conditions for resolution existed. Furthermore, in the nineteenth century, when Canada was still a subordinate part of the British Empire, the authority of the Judicial Committee of the Privy Council was much greater than that of any judicial body since.

21. Cairns, The Govemments and Societies of Canadian Federalism, 10 CAN. J. POL. SCI. 698, 698-99 (1977).

22. Id. at 720 .

23. Id. at 721 . 
At the present time most of the conditions for conflict resolution are adverse. Conflicts over jurisdiction reflect real differences in policy objectives, making compromise difficult. The format of the federal-provincial conference also tends to enhance disagreement. Whereas in the early years the meetings were closed, and a provincial premier was normally accompanied only by his attorney-general, they are now vast conclaves, jammed into what was once the magnificent concourse of the Ottawa Railway Station. Participants are constantly distracted by the steady flow of memoranda, every line of which is carefully analyzed for hidden meaning. Meanwhile, at the opening and closing sessions, the principals are pinned under the television lights as they read discourses intended to be consumed by their own electorates, who need to be reassured that their champion is posturing for their benefit and protection. Even the press interviews of each head of government are carefully monitored by the others so that a response can be mounted at once. The atmosphere is that of a summit of great powers, rather than of a closed diplomatic conference seeking diplomatic solutions. When the participants finally withdraw from the public, their attitudes and positions have hardened to the point where negotiation is almost impossible.

If in fact the machinery for the negotiation of constitutional change is faulty, what are.the prospects for constitutional adjustment in the future, and how will the changes materialize? The great patriation exercise involved a concentrated effort of time and energy which will not be easy to mobilize again. Both levels of government have strongly held views on the subject matter of Round Two of the constitutional talks, which will involve the thorny question of the repartition of jurisdiction. However necessary this may seem to the principals in the discussion, it is questionable whether they can summon the sense of urgency to begin negotiations all over again. Furthermore, delay might have a calming effect on the relations between Quebec and the rest of Canada. The urgent practical problems of economic recovery are likely to engage the full attention of all governments, and a renegotiation of the five-year fiscal agreements will compel the parties to concentrate their resources on that issue.

It seems likely that a much greater part of the process of constitutional adjustment will take place in the courts. Ten years ago it was possible for Richard Simeon to say that the "Canadian Supreme Court . . . has not so far established itself as an important factor in federal-provincial relations. . . It appears unlikely the Court will play a much larger part in the future."24 One of the reasons why one cannot say the same today is the inclusion of a Charter of Rights in the new constitutional document. Challenges to federal and provincial legislation can be expected from individuals and groups on the new ground of infringement of the Charter, which inevitably will raise side issues of jurisdiction as well.

In the past the principal actors in constitutional cases have been the governments and corporations with long purses and substantial financial interests at stake. There has been little participation of concerned citizen groups which loom so large in litigation in the United States, where so many constitutional issues arise

24. R. SIMEON, supra note 12 , at 30 . 
from the Bill of Rights. In Canada, part of the reason for this low individual participation level has been the existence of very strict rules governing locus standi, so that a litigant has needed to demonstrate a direct and usually pecuniary interest in the outcome in order to be heard. One of the few exceptions that come to mind is the case of Co-operative Committee on Japanese-Canadians v. Attomey-General of Canada. ${ }^{25}$ A much more usual type of intervention is illustrated by the Canada Temperance Federation (which seems to have been a lobby for the liquor interests) or by the Distillers and Brewers' Association of Ontario, which intervened in the Local Prohibition Case in 1896. ${ }^{26}$

In recent years the Supreme Court of Canada has given a much wider interpretation to the locus standi rule, thus opening a way for "concerned citizens" to launch court challenges to laws to which they object on general constitutional grounds. ${ }^{27}$ Such interventions are likely to be much more numerous on issues raised by the Charter, while governments will be dragged into the process to defend their jurisdictions. In practice the application of the Charter will incidentally raise the older questions of jurisdiction again, so that however much governments in recent years have preferred negotiation to battles in the courts, they will now be even less able to make the choice themselves. This will bring us back to what Dicey identified as one of the principal methods of constitutional adjustment in federal states: substituting litigation for formal amendment. The fact that the Supreme Court is entrenched in the new constitution is likely to strengthen its authority at a time when its role is enhanced. ${ }^{28}$

Of course no one knows how the Court will handle the new Charter. They have felt comfortable for so long with the same old questions of jurisdiction that it will require a considerable intellectual effort for them to see constitutional law in an enlarged perspective. There was little evidence that their horizon was enlarged by the 1960 Bill of Rights, which merely sought to impose new norms on federal legislation. As Walter Tarnopolsky has shown, the majority of the Court shied away from the general propositions of the Bill of Rights whenever possible. ${ }^{29}$ Whenever they could decide a case on some narrower ground - such as the safeguards already in the Criminal Code-rather than on the wider and vaguer principles of the Bill of Rights, they did so. Because the Bill of Rights asserted that the rights specified "have existed and shall continue to exist" it was more comfortable to assume that parliament had always legislated with these principles in mind, so that statute law necessarily conformed to its norms. The only thing new was a directive to the courts to interpret the law beneficially in accordance with its principles. If the

25. [1947] A.C. 87 .

26. Cf. Attorney-General of Ontario v. Canada Temperance Federation, [1946] A.C. 193; AttorneyGeneral of Ontario v. Attorney-General of Canada, [1896] A.C. 348.

27. Thorson v. Attorney-General of Canada, [1975] 1 S.C.R. 138. For a general discussion of this point see Johnson, Locus Standi in Constitutional Cases after Thorson, 1975 PUB. LAW 137.

28. For a discussion of the limits on the capacity of the Court to make authoritative decisions on divisive constitutional questions see Mallory, Constraints on Courts as Agencies for Constitutional Change: The Canadian Case, 1977 Pub. LAW 406.

29. W. TaRnopolsky, The Canadian Bill of Rights (2d ed. 1975). 
same attitude persists, the net effect of the Charter and its vaunted liberties will be minimal.

What will be the result of the pressures for constitutional change in Canada in the foreseeable future? Alan Cairns has no doubt that the trend is towards greater decentralization, partly because of the growing significance and visibility of provincial activity, partly because of the apparent incapacity of the central government to carry out its role of central economic management, and not least because of the increasing difficulty of accommodating the highly self-conscious Quebec nationalism within the bounds of an otherwise uniform system. How far either the Supreme Court or the concerted efforts of government can find a way out of these contradictions is not a question to which a confident answer can be given. 
